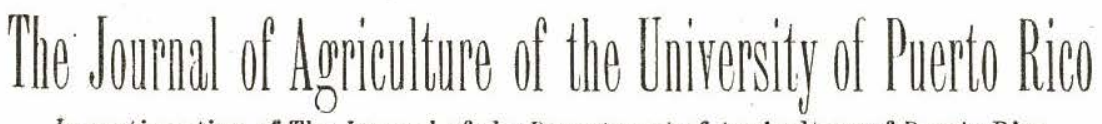

In continuation of The Journal of the Department of Agriculture of Puerto Rico

Published Quarterly: January, April, July and 0ctober of each year.

Melville T. CoOK, Edtur

VoL. XIX.

JANUARY 1935

No. 1.

\title{
EFFECT OF BORON ON THE GROWTH OF CERTAIN GREEN PLANTS *
}

\author{
By ANTONio RODRÍGueZ GÉigè,**
}

\section{INTRODUCTION}

In recent years considerable attention has been given to the elements manganese, copper zine and boron in relation to plant nutrition. Manganese has been definitely established as an essential element. The evidence for boron as an essential element is not as definite as the evidence for manganese but still it is fairly convincing. Like other elements boron at low concentration may increase plant growth while at higher concentrations boron is toxic. In general boron at concentrations in excess of one part per million has been found to be injurious to plants. This toxicity of boron is manifested by a distinct chlorosis of the leaves, defoliation and abscission of young fruits. Death may ultimately result from excess of boron.

Boron deficiency is of little practical importance in crop production, since there appears to be in most soils an adequate supply of available boron. Boron toxicity has been reported under certain conditions and is a problem of practical importance and may be a problem of greater importance than is generally recognized. Thus in Southern California and in the valley of the Río Grande in Texas, fruit trees have been reported as injured by boron. These conclusions are based on the character of the injury, i. e. chlorosis, defoliation and abscission of fruit and evidence on the presence in the plant and irrigation water of unusual amounts of boron. The fact that cholorosis is associated with boron injury suggests that boron interferes in some manner with the nomal iron or manganese relationships. It further suggests that bo may owe its favorable effects on plants by counteracting or antidoting the toxicity of iron or manganese particularly the former since in general less attention has

* A thesis presented to the faculty of the graduate school of Cornell University as partial fulfillment requirements for the degree of Doctor of Philosophy.

** Ohief, Division of Agricultural Industries, Department of Agriculture and Commerce. 
been given to the quantity of iron added to the culture medium than that of manganese.

This investigation is concerned with the toxicity of boron and more specifically with a possible relation of iron to boron. Three hypotheses have been advanced to account for boron toxicity. Boron may have a direct influence on chlorophyll resulting in its destruction. (2) Boron may have an effect on iron which is essential for cholorophyll formation. The solubility of iron may possibly be decreased either in the culture medium in the soil, or in the plant. (3) There is the possibility also that in the presence of boron there is a decreased permeability of the cell to iron or a lesser accumulation of iron. Similar relations might hold with respect to manganese.

The problem of boron toxicity is one of theoretical as well as practical importance. Basic studies are essential for the development of practical method of control.

\section{REVIEW OF THE Literature}

Boron seems to be widely distributed and probably occurs in all green plants. Wittstein and Apogier (35) in 1857 were the first to claim the presence of boron in plants. Baumert (2) 1888 detected boron in wines. E. O. Von Lippman (20) 1888 demonstrated its presence in the leaves and roots of sugar beets. Hotter (14) 1890 analyzed various fruits, leaves and twigs of certain plants finding boron present in apple, pear, cherry and others. H. Jay (15) 1895 analyzed various plants and concluded that boron is of universal occurrence in the plant world. He also stated that plants varied in their capacity for absorbing boron.

In recent years the problem of the stimulative action and the essential nature of boron has attracted the attention of various investigators. Nakamura (25) 1903 using peas and spinach in pots with soil found that the addition of one milligram of borax per killogram of soil exerted a stimulant action while 5 milligrams had a slight depressing action. Agulhon (1) 1910 in his exhaustive studies using sand, water and soil eultures found that boron was beneficial for plant growth. Brenchley (3) 1914 using barley and peas in water cultures gave evidence of st:mulation with the lower concentrations. With barley stimulation was not very evident. K. Warrington (33) 1923 in her extensive work on the effect of boron compounds on the broad beans and other plants, using water cultures, soil cultures, and field experiments, concluded that boron is an essential element. Warrington held the view that boron functioned catalyt- 
ically in the plant. Plants showed variations as to the need for boron. Seasoned variation was important. Lack of boron affects meristematic tissues. Brenchley and Thornton (4) 1925 presented. evidence to show that the absence of boron from the culture medium does not affect the entrance of the legume organism into the plant roots, but rather that gorwth of the plant without boron has affected the development of the nodules. The vascular supply of the nodules, was defective. Such nodules having no vascular strands remained small and buried in the cortical tissues. In nodules without vascular strands the bacteria do not give rise to bacteroid forms. There was a reduction in nitrogen fixation. Warrington (34) 1926 in her studies on the changes induced in the structure of Vicia Faba, by the absence of boron from the nutrient solution, found hypertrophy of the cambium, frequent disintegration of the phloem and ground parenchyma, and poor development of xylem with ultimate breaking of this tissue.

Sommer and Lipman (31) in 1926, using conductivity water and highly purified chemicals, presented photographic evidence showing that boron is essential for the growth of green plants. Brenchley and Warrington (5) in their study on the role of boron in the growth of plants reported complete failure of growth in the absence of boron. In the absence of boron, irrespective of the $\mathrm{pH}$ of the nutrient medium death ultimately occurred. They obtained better growth with a solution having a $\mathrm{pH}$ of 6.2. In their study on the influence of the concentration of boron on growth, they claim that the critical factor is the absolute amount of boron available in any one period and that concentration is not important so long as the rate of replacement is rapid enough to supply the required amount. A lower concentration of boron will suffice if the nutrient solution is frequently renewed. They stated that the form in which boron is present is of no importance and that sufficient amounts can be obtained from thê insoluble borates. Boron could not be replaced by any other element and could not replace any of the essential elements. The authors claim that without boron, calcium is not fully utilized and that boron enables the plant to actually obtain more calcium or utilize it more efficiently in metabilism. Swanback (32) 1927 presented evidence indicating that boron is essential for the growth of tobacco. Collins (6) 1927 using sand, soil and water cultures claimed that boron is not necessary during the seedling stage. He obtained no stimulation by boron and concluded that boron is not necessary for the production of a mature soy bean plant. Johnston and Dore (17) 
1928 from their study on the influence of boron on the chemical composition and growth of the tomato plant concluded that boron in concentration of 0.5 parts per million is necessary for the normal growth and development of the tomato plant. With a deficiency in boron they noted death of the terminal meristem and breaking down of conducting tissues in the stem. They found more total sugar and starch in the leaves and stems of boron-deficient plants and relate this to deficient conducting tissue. McMurtry (23) in 1929 corroborated the results obtained by Swanback. McHargue (21) 1930 also found a marked stimulation of growth with the use of boron. In a later paper (22) 1932 he describes special symptoms obtained with lettuce when boron was deficient. 'A. R. C. Haas (8) (9) (10) working with citrus trees has reported the necessity of small amounts of boron for their growth.

The various investigators who have dealt with the essential nature of boron have also studied the range in which boron is toxic. In general they have found that boron in concentrations above one part per million is toxic to plants. Such toxicity is marked by a chlorosis, defoliation and shedding of young fruits.

The problem of boron toxicity has become important in the dry regions of California and Southern Texas. Fruit trees of these regions have been affected with a chlorosis and final shedding of leaves and young fruits, thus causing damage of economic importance. The cause of this injury has been studied by various investigators. Kelley and Brown (19) found that boron is a natural constituent of the irrigation waters of Southern California. Subsequent investigations by Scofield and Wilcox (26) have confirmed these earlier reports and on the basis of their findings they concluded that boron is the cause of the injury to the crops of these regions. They stress the fact that the severity of crop injury resulting from boron may be influenced by local soil conditions, by climatic conditions, by method or quantity of irrigation and by the program of fertilization.

Skinner, Brown and Reid (28) in studying the effect of borax on plants made field experiments with various crops. They found borax when applied under field conditions to retard growth and crop yield. They refer repeatedis to a "bleaching" of the leaves though reduced yield was noted without chlorosis. With corn they state that badly bleached plants were obtained when borax was used in amounts greater than 5 pounds per acre. They suggest "this prevention of chlorophyll formation may be due to an interference with the assimilation of iron, similar to the action of calcium or as 
observed with an excess of manganese compounds." Tip burn has also been noted by these investigators as well as by others.

Summarizing the results of these various investigations, the conclusions are that boron at concentrations in excess of one part per million is toxic and that boron is essential for the growth of green plants. No evidence is available concerning the role played by boron. Views concerning the role of boron in relation to iron and toxicity have been stated previously.

\section{Experimental Methods}

In all of the previous work on boron, higher plants have been used which normally grow on soils. In my own experiments I selected two water plants, one of the duckweeds, Spirodela polyrhyza, a higher plant, and the other a species of Chlorella a unicellular alga. The former was obtained from Dr. Albert Saeger, who maintained it under pure culture condition. The alga was originally obtained from the soil by Wann and Hopkins (11) and has been maintained under pure culture conditions.

These plants were selected because their relation to iron and manganese has been well established, and it is possible to grow these in large numbers under uniform conditions. Thus, statistically such results as might be obtained should be significant.

In the experiments with Spirodela the plants were grown both under pure culture conditions and under ordinary water culture methods. With Chlorella, however, all the experiments were made under pure culture condition. With the Spirodela experiments, under ordinary culture conditions, ten plants were removed from the stock culture and transferred to the beakers containing the solutions under consideration. In the pure cultures only one plant was transferred to each culture at the outset of the experiment. Attention was given to the selection of uniform plants.

The stock cultures of Chlorella are maintained on potato-dextrose agar, a medium excellent for the growth of the alga. In starting cultures for the experimental work the following procedure was adopted. A small mass of cells was removed from the agar slope by means of the platinum needle and added to 10 cc. of sterile distilled water. This was agitated well until thorough suspension of cells was obtained. To the culture medium was then added one cubic centimeter of the suspension by means of a sterile pipette.. The suspension used in the various experiments was made to contain approximately the rame number of cells. 
The cultures after inoculation were placed on a table in the laboratory in front of a window where sufficient light was available for good development. The arrangement of the cultures was changed daily in order to eliminate differences in illumination.

Counts of the number of plants formed in the cultures of Spirodela were made from time to time during the course of the experiments. The number of leaves was also used as an index of growth. The dry weight of Spirodela was determined by drying the plants in vacuum oven at 50 degrees centigrade. In the experiments under ordinary cultural conditions, half of the plants were used to determine the dry weight, while those under pure culture conditions, the total number of plants was used.

The dry weight of the alga was obtained by filtering the culture through weighed gooch crucibles and then washing the cells in distilled water. The crucibles were then dried in a vacuum oven at 50 . degrees centigrade and the final weight obtained.

The water used in the preparation of the cultures was obtained from an electric still. The chemicals used were Kalbaums and these were recrystallized three times. A nearly saturated solution of the salt in hot conductivity water was made. This was filtered while hot to remove detritus. The solution was then chilled in a cold alcohol bath and the resulting crystals were collected on a buchner funnel. This process was thereafter repeated twice. The sugars used were Mercks sucrose U.S.P.X. and dextrose, Bakers's Blue Label. These were not recrystallized since they gave no test for iron.

Iron determination. Ten cubic centimeters of the solution are placed in a 50 ce. Nessler tube. To this is added 1 ce. of concentrated $\mathrm{HC} 1,1$ ce. of a solution of $\mathrm{KSO}_{4}$ (potassium persulphate) containing 5 milligrams of $\mathrm{KSO}_{4}$ per ce., and 10 ce. of a 10-per-cent solution of KSCN (potassium sulfocynate.) Fifteen ec. of an amylic mixture containing 5 parts of amyl alcohol and 2 parts of ether is then added. This is then mixed thoroughly with a vertical motion using a glass rod with a flat end in order to allow the amylic mixture to take up all the $\mathrm{Fe}(\mathrm{SCN})_{3}$. The mixing should not be violent, otherwise an emulsion may be formed, giving the upper layer a turbid appearance. When the two layers have separated, 5 ce. of the upper layer is removed by a pipette and placed in a colorimeter tube. Comparison with a standard is then made. The standard is prepared in exactly the same way having a known amount of iron present.

Boron analysis. The precipitation was obtained from the culture medium by centrifuging. It was washed with distilled water several 
times and then dissolved with concentrated HC1. The solution was made up to $50 \mathrm{cc}$. and an aliquot part taken to be tested with Tumeric paper. The Tumeric paper was allowed to stay in the solution from 24 hours to 48 hours.

\section{Experiments WitH Spirodela Polyrhyza}

The culture solution used for Spirodela was Knop's solution modified to the extent of obaining a balance medium which would give maximum growth without forming a precipitate. This solution will be designated as $\mathrm{K}-\mathrm{I}$.

$\begin{array}{ll}\mathrm{KNO}_{3} & 1.67 \mathrm{~g} . \\ \mathrm{KH}_{2} \mathrm{PO}_{4} & 1.67 \mathrm{~g} . \\ \mathrm{MgSO}_{4} & 0.81 \mathrm{~g} . \\ \mathrm{Ca}\left(\mathrm{NO}_{3}\right)_{2} 4 \mathrm{H}_{2} \mathrm{O} & 5.00 \mathrm{~g} . \\ \text { Water_} & \end{array}$

The culture medium used was made up by taking 10 ce. of the above stock solution and diluting it with the addition of 990 cc. of distilled water. $\mathrm{MnSO}_{4} 4 \mathrm{H}_{2} \mathrm{O}$ was added so that the concentration of manganese would be 0.1 p.p.m. Iron was added in 0.5 p.p.m. as $\mathrm{FeC1}_{3}$ unless otherwise specified.

\section{Experiment 1.}

In this experiment the plants were grown under ordinary water culture methods. Beakers of 400 ce. capacity, of pyrex gla ss, were used. These were covered with Petri dishes to prevent the entrance of dust. In each beaker was placed 250 cc. of the culture solution. At the outset of the experiment 10 plants were transferred from the stock culture to each culture vessel. At the beginning all cultures were in duplicate but later in the experiment the individual treatments were replicated four times. The culture solutions were changed every three or four days and observations were made at these times on the color of the plants and root conditions. Counts were made also of the number of plants per culture. The results of this experiment are summarized in Table 1 and presented graphically in Figure 1.

When the data under date of April 11 are noted it will be observed that there appears to be a marked stimulation of growth by concentrations in excess of 30 p.p.m. The large number of plants is due not to increased growth but to a breaking up of the original plant into many smaller individuals consisting usually of single leaves. This is characteristic of the duckweeds when an unfavorable 
condition is present and is to be taken as evidence of toxicity. These individuals soon die so that in the figures given under April 21 no data are recorded for these cultures with the highest concentrations. Furthermore, the final figures on the number of plants do not reflect fully the differences in growth between the boron-treated plants and the controls, since the plants with boron were generally smaller. This will be referred to again subsequently.

The controls were not of a deep green color indicating that iron was in part deficient, but those plants with boron were more deficient in chlorophyll.

TABLE 1-INFLUENCE OF BORON ON GROWTH OF SPIRODELA. BORON ADDED AS BORIC ACID. EXPERIMENT BEGUN APRIL 7 WITH 10 PLANTS IN EACH CULTURE.

\begin{tabular}{|c|c|c|c|c|c|}
\hline \multirow{2}{*}{ Treatment } & \multicolumn{3}{|c|}{ Number of Plants per Culture } & \multirow{2}{*}{$\begin{array}{l}\text { Ave. No. } \\
\text { Plants } \\
\text { April } 21\end{array}$} & \multirow{2}{*}{ Condition } \\
\hline & April 11 & April 16 & April 21 & & \\
\hline 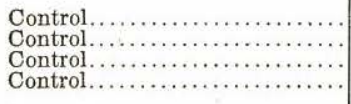 & 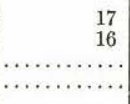 & 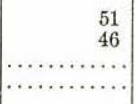 & $\begin{array}{r}100 \\
110 \\
94 \\
92\end{array}$ & $\begin{array}{l} \\
\ldots \ldots \ldots \cdots \cdots \\
\cdots \cdots \cdots \cdots \cdots\end{array}$ & $\begin{array}{l}\text { Slight } \\
\text { Chlorosis } \\
\ldots \ldots \ldots \ldots \ldots \ldots \ldots \ldots\end{array}$ \\
\hline 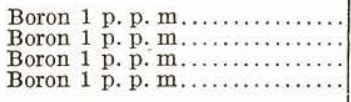 & $\begin{array}{r}12 \\
12 \\
\ldots \ldots \ldots \cdots \cdots \\
\cdots \cdots \cdots\end{array}$ & $\begin{array}{r}38 \\
28 \\
\ldots \ldots \ldots \ldots \\
\cdots \cdots \cdots \cdots\end{array}$ & $\begin{array}{l}50 \\
54 \\
54 \\
60\end{array}$ & 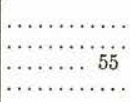 & $\begin{array}{l}\text { Chlorotic } \\
\text { CW. }\end{array}$ \\
\hline 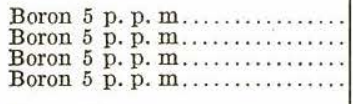 & $\begin{array}{r}10 \\
15 \\
\ldots \ldots \ldots \cdots \cdots \\
\cdots \cdots \cdots \cdots\end{array}$ & 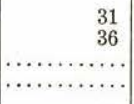 & $\begin{array}{l}24 \\
24 \\
24 \\
24\end{array}$ & $\begin{array}{l}\cdots \cdots \cdots \\
\ldots \ldots \cdots \cdots \cdots \\
\cdots \cdots \cdots \cdots \cdots\end{array}$ & $\begin{array}{l}\text { Chlorotic and } \\
\text { plants smaller }\end{array}$ \\
\hline 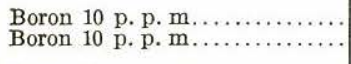 & $\begin{array}{l}12 \\
10\end{array}$ & $\begin{array}{l}30 \\
32\end{array}$ & $\begin{array}{l}22 \\
22\end{array}$ & n.......... & $\begin{array}{l}\text { Chlorotic and } \\
\text { plants smaller }\end{array}$ \\
\hline 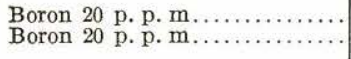 & $\begin{array}{l}10 \\
11\end{array}$ & 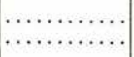 & & & \\
\hline $\begin{array}{l}\text { Boron } 30 \text { p. p. m } \ldots \ldots \ldots \ldots \ldots \ldots \\
\text { Boron } 30 \text { p. p. ma } \ldots \ldots \ldots \ldots \ldots\end{array}$ & $\begin{array}{l}13 \\
16\end{array}$ & a & n.......... & & Plants very small \\
\hline $\begin{array}{l}\text { Boron } 40 \text { p. p. m } \ldots \ldots \ldots \cdots \cdots \cdots \\
\text { Boron } 40 \text { p. p. } m \ldots \ldots \cdots \cdots \cdots \cdots\end{array}$ & $\begin{array}{l}22 \\
30\end{array}$ & (n) & 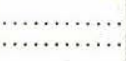 & $\ldots \ldots \cdots \cdots$ & chlorotic \\
\hline 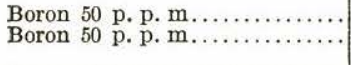 & $\begin{array}{l}33 \\
34\end{array}$ & $\mid \cdots \cdots \cdots \cdots \cdots$ & n.w. & & $\int$ \\
\hline
\end{tabular}

The chlorosis noted in the plants grown with boron began with a discoloration at the tip of the lobes spreading down to the base of the lobes. The possibility of iron being deficient in the solution and causing the chlorotic appearance was considered. Iron was added 0.125 parts per million to one culture in each series. The addition of this extra iron as $\mathrm{FeCI}_{3}$ did not correct the chlorosis. The reason for this lack of response to extra iron will be presented and discussed subsequently. It was still assumed that iron was unavailable. With this point in mind 20 parts per million of potassium tartrate was added to each of the cultures in which the amount of iron had been 
increased. The results of the addition of potassium tartrate were observed four days later. All the cultures to which it had been added became green and normal in color. Algal growth in the solution containing the tartrate also showed the beneficial effect of the treatment.

In summarizing these results boron was found to be detrimental to growth. Signs of its toxic action were shown by the chlorosis of the leaves, loss of roots and general decrease in size and growth. The addition of potassium tartrate induced chlorophyll formation.

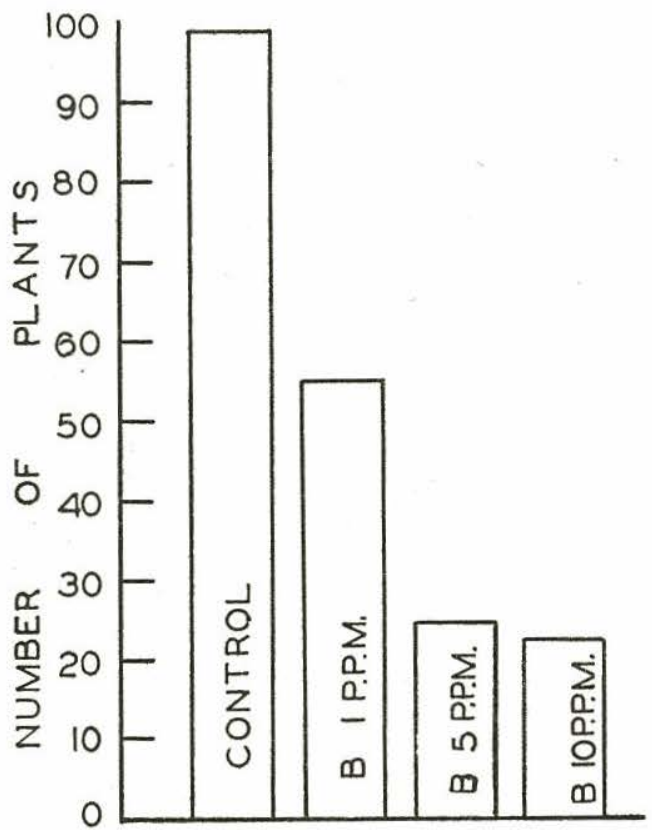

Figure 1.-Influence of boron on growth of Spirodela polyrhyza based on average number of plants in cultures on April 21.

Experiment 2.

In this experiment the culture conditions were essentially like those of the preceding experiment except that potassium tartrate was used in half of the cultures. The tartrate was added as a means of maintaining the availability of iron. This has been used repeatly for this purpose and in Experiment 1 proved effective in inducing chlorophyll formation. As in the previous experiment iron was added at the rate of 0.5 p.p. m. To reduce algae contamination the solutions were renewed at intervals of four to six days. 
TABLE 2-EFFECT OF BORON ON SPIRODELA POLYRHYZA. EXPERIMENTS BEGUN ON APRIL 26. TEN PLANTS WERE INITIALLY PLACED IN EACH CULTURE. FIGURES REPRESENT AVERAGE OF FOUR CULTURES.

\begin{tabular}{|c|c|c|c|c|c|c|}
\hline \multirow[b]{2}{*}{ Treatment } & \multirow[b]{2}{*}{$\begin{array}{l}\text { No. of } \\
\text { Plants* }\end{array}$} & \multicolumn{2}{|c|}{ May 13th } & \multirow[b]{2}{*}{$\begin{array}{l}\text { No. of } \\
\text { Plants* }\end{array}$} & \multicolumn{2}{|c|}{ June 6 th } \\
\hline & & $\begin{array}{l}\text { Dry } \\
\text { Wt. }\end{array}$ & $\begin{array}{l}\text { Relative } \\
\text { Dry Wt. }\end{array}$ & & $\begin{array}{l}\text { Dry } \\
\text { Wt. }\end{array}$ & $\begin{array}{l}\text { Relative } \\
\text { Dry Wt. }\end{array}$ \\
\hline 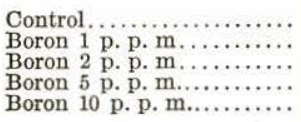 & $\begin{array}{r}20 \\
66 \\
57 \\
52 \\
45\end{array}$ & $\begin{array}{r}22.4 \\
31.6 \\
37.9 \\
30.8 \\
5.3\end{array}$ & $\begin{array}{l}100 \\
141 \\
168 \\
137 \\
23.6\end{array}$ & $\begin{array}{r}45 \\
34 \\
29 \\
047 \\
\text { Dead....... }\end{array}$ & $\begin{array}{l}32.5 \\
33.5 \\
24.9 \\
25.1\end{array}$ & $\begin{array}{r}100 \\
103 \\
76.6 \\
77.0 \\
\ldots \ldots \ldots \ldots\end{array}$ \\
\hline
\end{tabular}

- Plants small due to fragmentation.

* Plants were removed at definite intervals from each culture, the percentage removed from all flasks being the same.

After May 13th the plants in some of the cultures became too numerous and it was necessary to remove half of the plants from all cultures at this time. Those removed were used for dry weight determination. Subsequent removals of plants were made so that the plants were halved on May 19, 24, and 31. The plants were halved therefore four times. No figures are given to show the total number of plants that would have been produced if the containers had been sufficiently large with adequate volume of solution, and no reduction in the number of plants, as has been done by others.

TABLE 3-EFFECT OF BORON ON SPIRODELA IN THE PRESENCE OF POTASSIUM TARTRATE. EXPERIMENT BEGUN APRIL 26. TEN PLANTS WERE INITIALLY PLACED IN EACH CULTURE. FIGURES REPRESENT AVERAGE OF FOUR CULTURES.

\begin{tabular}{|c|c|c|c|c|c|c|}
\hline \multirow[b]{2}{*}{ Treatment } & \multirow[b]{2}{*}{$\begin{array}{l}\text { No. of } \\
\text { Plants* }\end{array}$} & \multicolumn{2}{|c|}{ May 13th } & \multirow[b]{2}{*}{$\begin{array}{l}\text { No. of } \\
\text { Plants* }\end{array}$} & \multicolumn{2}{|c|}{ June 6th } \\
\hline & & Dry wt. & $\begin{array}{l}\text { Relative } \\
\text { Dry Wt. }\end{array}$ & & Dry Wt. & $\begin{array}{l}\text { Relative } \\
\text { Dry Wt. }\end{array}$ \\
\hline 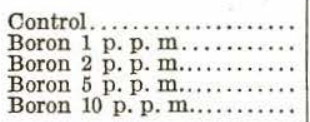 & $\begin{array}{r}37 \\
51 \\
47 \\
045 \\
050\end{array}$ & $\begin{array}{r}26.4 \\
37.2 \\
39.1 \\
21.5 \\
6.8\end{array}$ & $\begin{array}{l}100 \\
141 \\
148 \\
81.4 \\
25.7\end{array}$ & $\begin{array}{r}83 \\
52 \\
42 \\
{ }^{\circ} 70 \\
\text { Dead..... }\end{array}$ & $\begin{array}{r}64.2 \\
36.8 \\
32.1 \\
13.4 \\
\cdots\end{array}$ & $\begin{array}{r}100 \\
57.4 \\
50.6 \\
20.8 \\
\ldots \ldots\end{array}$ \\
\hline
\end{tabular}

- Plants small due to fragmentation.

* Plants were removed at definite intervals from each culture, the percentage removed from all flasks being the same.

The detailed data are given in Tables 2 and 3 relative values are combined in Table 4. It should be noted that for the initial period of growth boron at concentration of from 1 p.p.m. to 5 p.p.m. actually increased the number of plants produced and the dry weights. This was true when the plants were grown without tartrate and with tartrate, though with the latter there was no stimulation of growth with $\mathbf{5}$ p. p. m. In the later periods of growth there was a marked decrease in yield with all concentrations of boron except in the cultures con- 
taining 1 p. p. m. of boron without tartrate. Ten parts per million of boron were markedly toxic. In the culture without tartrate chlorosis was more pronounced than in the controls at the close of the experiment.

TABLE 4-INFLUENCE OF BORON ON SPIRODELA WITH AND WITHOUT TARTRATE. RELATIVE VALUES OF DRY WEIGHTS.

\begin{tabular}{|c|c|c|c|c|}
\hline \multirow{2}{*}{ Treatment } & \multicolumn{2}{|c|}{ May 13} & \multicolumn{2}{|c|}{ June 6} \\
\hline & Tartrate & $\underset{\text { Tartrate }}{+}$ & Tratrate & $\underset{\text { Tartrate }}{+}$ \\
\hline 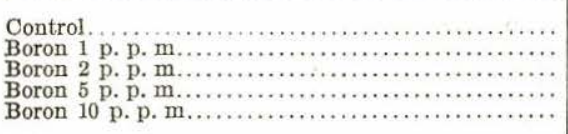 & $\begin{array}{l}100 \\
141 \\
168 \\
137 \\
23.6\end{array}$ & $\begin{array}{l}100 \\
141 \\
148 \\
81.4 \\
25.7\end{array}$ & $\begin{array}{c}100 \\
103 \\
76.6 \\
77 \\
\text { Dead....... }\end{array}$ & $\begin{array}{r} \\
\\
\\
\\
57.4 \\
50.6 \\
\\
20.8 \\
\text { Dead }\end{array}$ \\
\hline
\end{tabular}

Volume of solution-250 cc.

Experiment 3.

In order to test the effect of potassium tartrate on boron toxicity under controlled conditions, experiments were started using pure culture methods. The nutrient culture solution used was the same as that of the preceding experiments. The concentration of boron ranged from 0.5 to 5.0 p.p. m. Potassium tartrate was also added to half of the cultures in concentration of 20 p.p.m. One sterile plant of Spirodela was transferred to each culture. The cultures were kept at room temperature near a window and were allowed to grow for five weeks. The results obtained are presented in Table 5 . They are shown graphically in Figures 3 and 4.

TABLE 5-EFFECT OF BORON ON SPIRODELA UNDER PURE CULTURE CO NDITIONS WITH AND WITHOUT TARTRATE. ONE PLANT WAS INITIALLY PL ACED IN EACH CULTURE.

\begin{tabular}{|c|c|c|c|c|c|c|}
\hline \multirow[b]{2}{*}{ Treatment } & \multicolumn{3}{|c|}{ With Potassium Tartrate } & \multicolumn{3}{|c|}{ Without Potassium Tartrate } \\
\hline & $\begin{array}{l}\text { Average } \\
\text { No. of } \\
\text { Plants }\end{array}$ & $\begin{array}{c}\text { Average } \\
\text { Dry } \\
\text { Weight }\end{array}$ & $\begin{array}{c}\text { Relative } \\
\text { Dry } \\
\text { Weight }\end{array}$ & $\begin{array}{l}\text { Average } \\
\text { No. of } \\
\text { Plants }\end{array}$ & $\begin{array}{c}\text { Average } \\
\text { Dry } \\
\text { Weight }\end{array}$ & $\begin{array}{c}\text { Relative } \\
\text { Dry } \\
\text { Weight }\end{array}$ \\
\hline 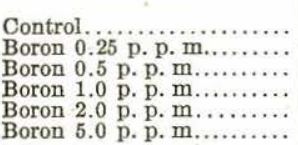 & $\begin{array}{l}53 \\
56 \\
49 \\
65 \\
55 \\
12\end{array}$ & $\begin{array}{r}21.7 \\
24.5 \\
23.9 \\
26.0 \\
20.4 \\
1.4\end{array}$ & $\begin{array}{c}100 \\
112 \\
110 \\
119 \\
94 \\
6.3\end{array}$ & $\begin{array}{l}33 \\
34 \\
38 \\
36 \\
53 \\
29\end{array}$ & $\begin{array}{r}14.7 \\
12.4 \\
17.2 \\
16.1 \\
18.7 \\
2.7\end{array}$ & $\begin{array}{l}100 \\
84.3 \\
119 \\
109 \\
127 \\
18.3\end{array}$ \\
\hline
\end{tabular}

Duration of experiment- 5 weeks.

Figures are averages of 3 cultures.

Volume of solution-250 cc.

Boron proved to be extremely toxic at five parts per million both with and without tartrate. With two exceptions greater growth was 
obtained when boron was present at concentrations of 2 p.p.m. or less. Potassium tartrate, while it maintains iron in solution, has no influence on the toxicity of boron. No chlorosis was observed in any of these cultures.

\section{Experiment 4.}

Various investigators (27) (28) have suggested that boron toxicity may be related to deficiency of iron, and that chlorosis observed with high boron content is the result of an iron deficiency rather than to a direct action of boron. The results in my own experiments suggest a similar relationship though subsequently no chlorosis was

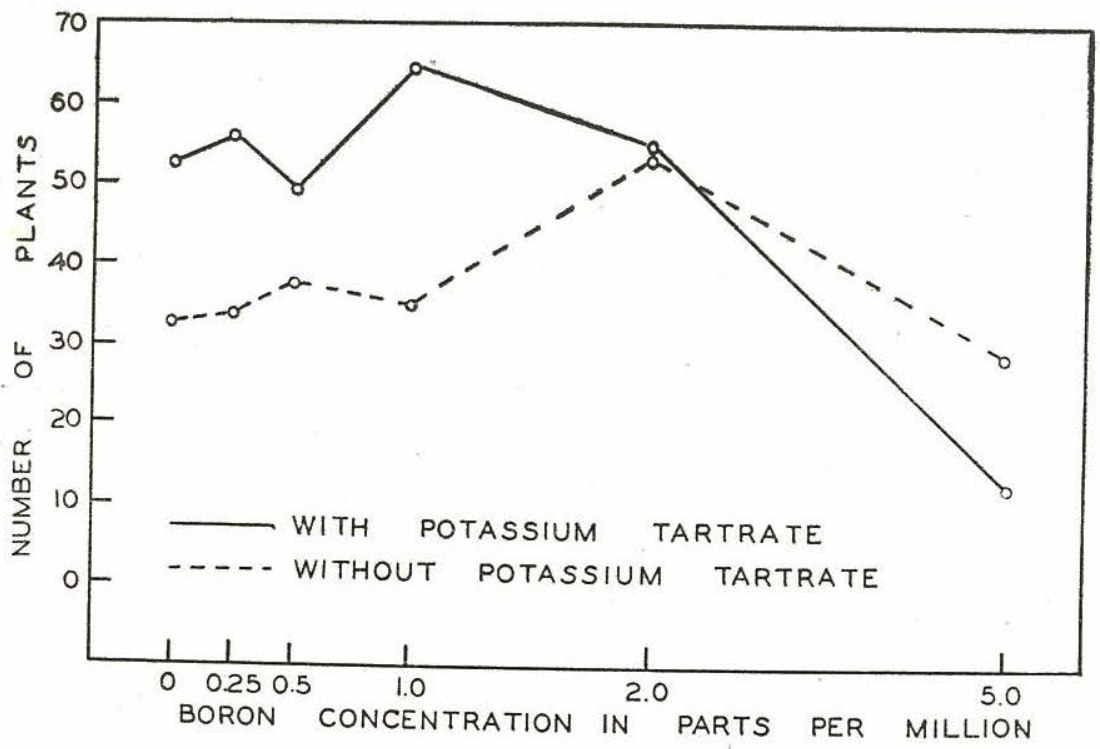

Figure 2.-Influence of boron on growth of Spirodela.

noted. In Experiment 4 an attempt was made limiting the higher concentrations of boron. The data are given in Table 6 . There are some discrepancies in the analysis of iron in the series without tartrate and more iron remains available with tartrate than without tartrate. Nevertheless the toxic influence of boron still prevails at concentrations in excess of 2 p. p. m. and even at some of the lower concentrations.

Experiment 5 .

To determine the relation of boron to iron availability with and without potassium tartrate in the absence of plants the following ex- 
periment was started. The solution used was the same as that of preceding experiments. To the individual flasks containing $250 \mathrm{cc}$. of the nutrient solution boric acid was added to supply boron in the concentrations indicated in Table 7. Half of the cultures received 20 p. p. m. of potassium tartrate. The solutions were not sterilized. Hydrogen-ion and iron concentrations were determined daily for a period of seven days. The analysis made of these solutions on the day in which they were prepared showed no essential difference in the iron concentrations in the various cultures.

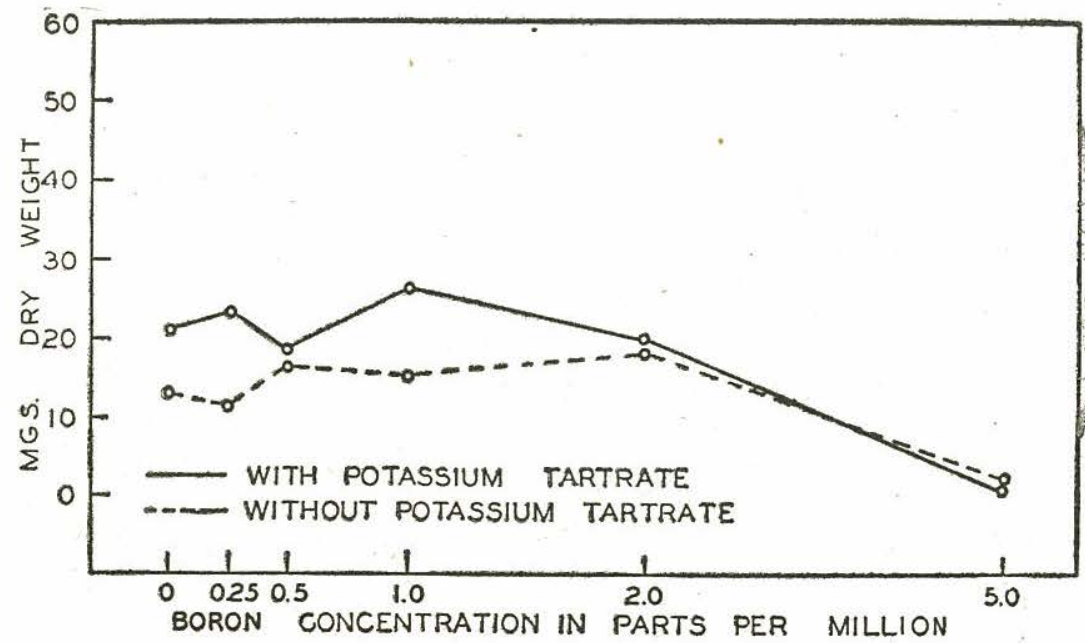

Figure 3.-Influence of boron on the dry weight of Spirodela.

TABLE 6-EFFECT OF BORON ON THE IRON CONCENTRATION. ONE PLANT WAS INITIALLY PLACED IN EACH CULTURE.

\begin{tabular}{|c|c|c|c|c|}
\hline \multirow[b]{2}{*}{ Treatment } & \multicolumn{2}{|c|}{ With } & \multicolumn{2}{|c|}{$\begin{array}{c}\text { Withont } \\
\text { Potassium Tartrate }\end{array}$} \\
\hline & $\begin{array}{l}\text { Average } \\
\text { No. of } \\
\text { Plants }\end{array}$ & $\begin{array}{c}\text { Average } \\
\text { Iron } \\
\text { Conc. }\end{array}$ & $\begin{array}{l}\text { Average } \\
\text { No. of } \\
\text { Plants }\end{array}$ & $\begin{array}{c}\text { Average } \\
\text { Iron } \\
\text { Conc. }\end{array}$ \\
\hline 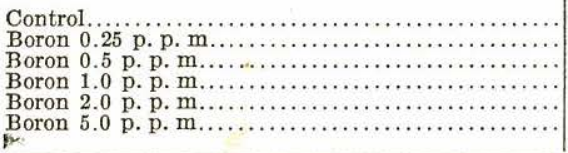 & $\begin{array}{r}92 \\
102 \\
108 \\
86 \\
58 \\
22\end{array}$ & $\begin{array}{l}0.1080 \mathrm{mgs} . \\
0.0860 \mathrm{mgs} . \\
0.1050 \mathrm{mgs} . \\
0.1180 \mathrm{mgs} .\end{array}$ & $\begin{array}{l}44 \\
47 \\
65 \\
55 \\
52 \\
30\end{array}$ & $\begin{array}{l}0.05 \text { mgs. } \\
0.022 \text { mgs. } \\
0.044 \text { mgs. } \\
0.050 \text { mgs. } \\
0.025 \text { mgs. } \\
\ldots \ldots \ldots \text {. }\end{array}$ \\
\hline
\end{tabular}

Volume of solution-250 cc.

Duration of experiment -5 weeks.

Figures are average of 3 cultures. 
All contained approximately about 0.125 mgs. of iron per flask. By the fourth day the available iron content of the tartrate series, which is shown in Table 7, was in excess of those without tartrate. Boron had no effect on the solubility of iron under these conditions. A flocculent and amorphous precipitate was present in the cultures the third day after they were prepared. This was evidently the reason for a decrease in the iron content.

TABLE 7-EFFECT OF BORON ON THE SOLUBILITY OF IRON ANALYSIS MADE 4 DAYS AFTER PREPARATION OF THE SOLUTION. AMOUNTS GIVEN ARE FOR $250 \mathrm{cC}$. OF THE CULTURE SOLUTION.

\begin{tabular}{|c|c|c|c|c|}
\hline \multirow[b]{2}{*}{ Treatment } & \multicolumn{2}{|c|}{$\begin{array}{l}\text { Without } \\
\text { Potassium Tartrate }\end{array}$} & \multicolumn{2}{|c|}{$\begin{array}{c}\text { With } \\
\text { Potassium Tartrate }\end{array}$} \\
\hline & $\mathrm{pH}$ & $\begin{array}{l}\text { Iron Conc. } \\
\text { Mgs. }\end{array}$ & $\mathrm{pH}$ & $\begin{array}{l}\text { Iron Conc. } \\
\text { Mgs. }\end{array}$ \\
\hline 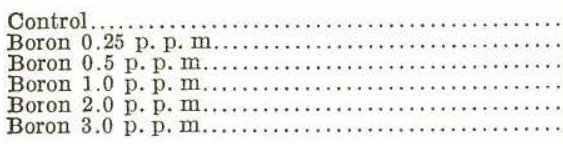 & $\begin{array}{l}5.16 \\
5.14 \\
4.9 \\
4.9 \\
4.9 \\
4.9\end{array}$ & $\begin{array}{l}0.022 \\
0.020 \\
0.020 \\
0.025 \\
0.022 \\
0.017\end{array}$ & $\begin{array}{l}6.7 \\
6.5 \\
6.6 \\
5.8 \\
5.8 \\
5.9\end{array}$ & $\begin{array}{l}0.025 \\
0.032 \\
0.032 \\
0.062 \\
0.050 \\
0.050\end{array}$ \\
\hline
\end{tabular}

Figures are average of four cultures.

Experiments With Chlorella sp.

The nutrient solution used in these experiments was a modified Knop solution, having the following composition:

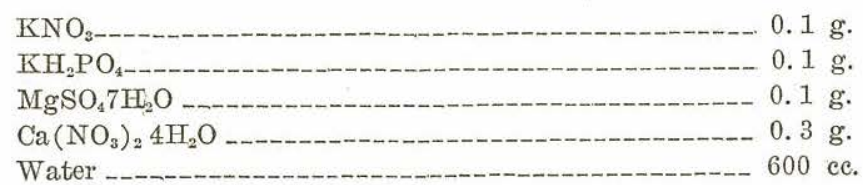

This solution was diluted by using 100 cc. of the above solution and 900 cc. of distilled water. $\mathrm{MnSO}_{4} 4 \mathrm{H}_{2} \mathrm{O}$ was added so that the concentration of manganese was 0.1 p. p. m. Iron was added in five tenths (0.5) p. p.m. as $\mathrm{FeCl}_{3}$ unless otherwise specified:

Chlorella was chosen for these experiments because the relation of this plant to iron had been studied carefully by Hopkins and Wann (11) and later Hopkins (13). Since it has been assumed by Sideris and Krauss (27) and Skinner, Brown and Reid (28) that boron toxicity may be related to the availability of iron, it seemed appropriate to select the iron relations which are so well established. The relation of iron to chlorophyll formation in Chlorella has been investigated by Emerson (7). Furthermore there is some advantage 
in using unicellular plant since complications due to internal precipitation of iron in the nodes are avoided.

\section{Experiment 6.}

In order to determine the tolerance of Chlorella to boron, an experiment was made using solution $\mathrm{K}-2$ to which boron was added in varying amounts. Potassium tartrate was added to half of these cultures at a concentration of 20 p.p. m. The tartrate was added as in previous experiments to increase the availability of iron. The results obtained are presented in Table 8 and in Figure 4 . With the tartrate present there appears to be a slight stimulation of growth with boron at a concentration of 1 to 20 p.p.m. inclusive. Less growth was noted at 30 p.p.m. Without tartate, stimulation was noted in eultures containing boron at 5 and $10 \mathrm{p.p.m}$. The reduction in yield at 30 p. p. m. was more pronounced in the cultures without tartrate than with tartrate.

Experiment $\%$.

The experiment was similar to the preceding except that sodium citrate at 20 p.p.m. was used instead of tartrate. The concentrations of boron was used in the range previously found to be stimulatory. The detailed data are given in Table 9. Marked stimulation of growth was noted in all the cultures containing boron. This was true whether citrate was used or not.

\section{Experiment 8.}

To obtain evidence on the possible action of boron in reducing iron toxicity, an experiment was started in which the iron concentration was varied from 0.5 to 10 p.p. m. Boron was kept constant at 20 p.p.m. Solution K-2 under pure culture methods was used. The initial and final ph of the various culture solutions were determined. This together with the dry weight of the cultures is presented in Table 10. When the solution was prepared it was noted that iron precipitation increased with an increase in iron concentration. During the first 20 days it was noted that growth was very slow in the cultures containing above 4 p. p. m. of iron. Afterwards growth became faster and at the end of 43 days the culture with 8 p.p.m. had almost attained the same amount of growth as those with 4 and 6 p.p.m. Had the experiment been concluded earlier more marked differences would have been noted in the yield between the lower and the higher iron concentrations. The results do not show any effect of boron on reducing iron toxicity since there is not a marked difference between the cultures with and without boron. 
TABLE 8-INFLUENCE OF BORON ON THE GROWTH OF CHLORELLA IN THE PRESENCE OF POTASSIUM TARTRATE.

\begin{tabular}{|c|c|c|}
\hline \multirow[t]{2}{*}{ Treatment } & $\begin{array}{c}\text { With } \\
\text { Potassium } \\
\text { Tartrate }\end{array}$ & $\begin{array}{l}\text { Without } \\
\text { Potassium } \\
\text { Tartrate }\end{array}$ \\
\hline & $\begin{array}{c}\text { Dry Weight } \\
\text { Mgs. }\end{array}$ & $\begin{array}{c}\text { Dry Weight } \\
\text { Mgs. }\end{array}$ \\
\hline 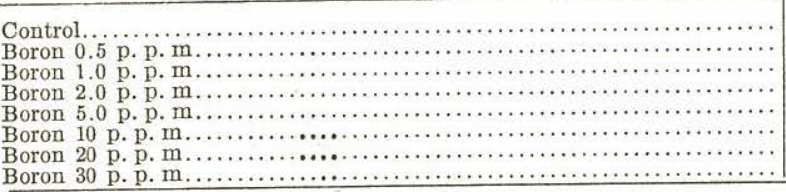 & $\begin{array}{l}31.9 \\
30.8 \\
33.6 \\
36.6 \\
34.7 \\
34.7 \\
34.1 \\
20.2\end{array}$ & $\begin{array}{l}23.7 \\
22.5 \\
20.9 \\
23.5 \\
26.8 \\
27.0 \\
22.3 \\
16.6\end{array}$ \\
\hline
\end{tabular}

Figures are averages of six cultures.

Age of the cultures - 40 days.

Volume of solution-250 $\mathrm{cc}$.

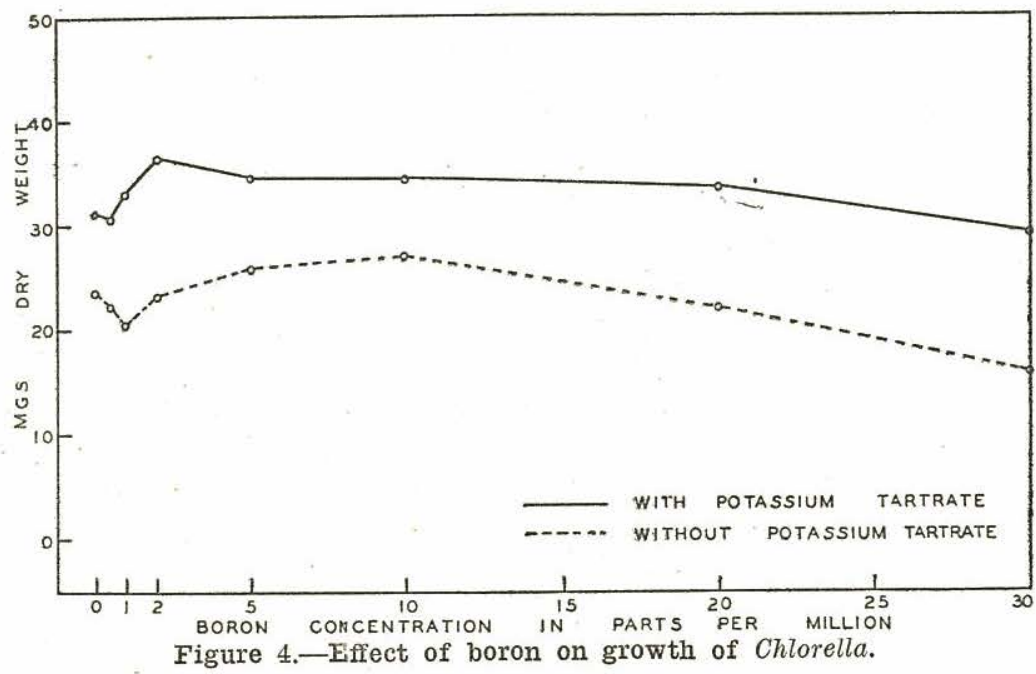

TABLE 9-INFLUENCE OF BORON ON THE GROWTH OF CHLORELLA IN THE PRESENCE OF SODIUM CITRATE.

\begin{tabular}{|c|c|c|}
\hline \multirow[t]{2}{*}{ Treatment } & $\begin{array}{l}\text { With } \\
\text { Sodium } \\
\text { Citrate }\end{array}$ & $\begin{array}{l}\text { Without } \\
\text { Sodium } \\
\text { Citrate }\end{array}$ \\
\hline & $\begin{array}{c}\text { Dry Weight } \\
\text { Mgs. }\end{array}$ & $\begin{array}{c}\text { Dry Weight } \\
\text { Mgs. }\end{array}$ \\
\hline 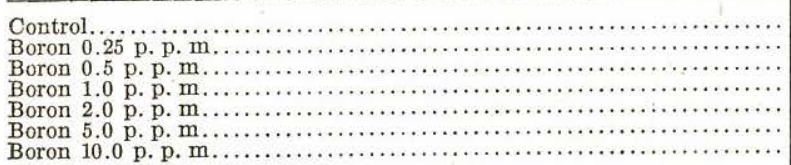 & $\begin{array}{r}7.0 \\
12.0 \\
12.0 \\
12.8 \\
12.1 \\
14.9 \\
18.5\end{array}$ & $\begin{array}{l}2.8 \\
2.9 \\
3.6 \\
3.8 \\
5.3 \\
6.7 \\
5.7\end{array}$ \\
\hline
\end{tabular}

The figures are averages of six cultures.

Age of the cultures-22 days.

Volume of solution-250 cc. 


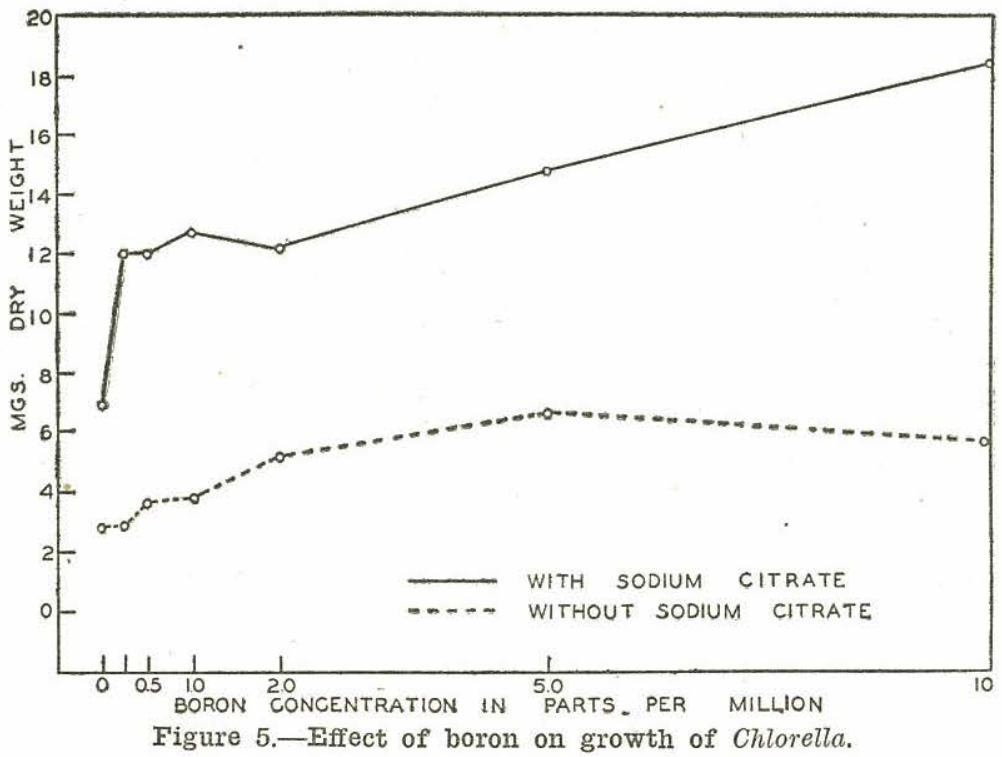

Experiment 9.

In the previous experiments with Chlorella little or no toxicity of boron was noted. Consequently in this experiment concentrations of boron up to 140 p. p. m. were used. The experiment was similar to experiments 7 and 8 except that the cultures were kept under a cheesecloth shade in the greenhouse, with temperatures prevailing from 20 degrees to 25 degrees C. Because of slow growth under these conditions the cultures were brought back to the laboratory after ten days where a higher degree of illumination was used. All the cultures were repeated six times and the figures given in Table 11 are the average of the six cultures.

TABLE 10-EFFECT OF INCREASING IRON CONCENTRATIONS ON THE GROWTH OF CHLORELLA IN THE PRESENCE OF BORON.

\begin{tabular}{|c|c|c|c|c|}
\hline Treatment & $\begin{array}{l}\text { Iron } \\
\text { Conc. }\end{array}$ & $\begin{array}{c}\text { Initial } \\
\mathrm{pH}\end{array}$ & $\begin{array}{c}\text { Dry Weight } \\
\text { Mgs. }\end{array}$ & $\begin{array}{l}\text { Final } \\
\mathrm{pH}\end{array}$ \\
\hline Full Nutrient. & p. p. $\mathrm{m}_{0.5}$ & 4.38 & 27.4 & 6.67 \\
\hline F. N.-Boron........... & $\begin{array}{l}0.0 \\
0.5\end{array}$ & $\begin{array}{l}4.30 \\
4.38\end{array}$ & $\begin{array}{l}21.4 \\
26.7\end{array}$ & $\begin{array}{l}0.07 \\
6.92\end{array}$ \\
\hline 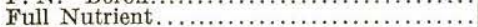 & 2.0 & 4.12 & 28.6 & 6.70 \\
\hline F. N.-Boron $\ldots \ldots \ldots \ldots \ldots \ldots \ldots \ldots \ldots \ldots \ldots \ldots \ldots \ldots \ldots \ldots$ & 2.0 & 4.12 & 28.9 & 6.67 \\
\hline Full Nutrient. $\ldots \ldots \ldots \ldots \ldots \ldots \ldots \ldots \ldots \ldots \ldots \ldots$ & 4.0 & 3.78 & 27.9 & 6.67 \\
\hline 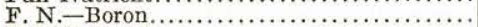 & 4.0 & 3.78 & 29.8 & 6.67 \\
\hline 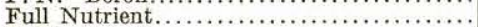 & 6.0 & 3.61 & 23.9 & 7.01 \\
\hline 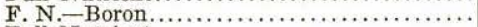 & 6.0 & 3.61 & 26.8 & 7.01 \\
\hline 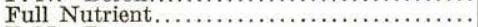 & 8.0 & 3.44 & 21.8 & 6.58 \\
\hline 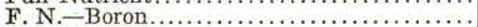 & 8.0 & 3.44 & 20.8 & 6.41 \\
\hline Full Nutrient................. & 10.0 & 3.44 & 18.2 & 5.14 \\
\hline F. N.-Boron .................. & 10.0 & 3.44 & 20.0 & 5.82 \\
\hline
\end{tabular}

Boron-20 p. p. m. as boric acid.

Iron as $\mathrm{FeC1}^{3}$.

Age of cultures-43 days.

Figures are averages of 4 cultures.

Volume of solution- $250 \mathrm{cc}$. 
The results show that with and without sodium citrate growth is decreased at all concentrations of boron as compared to the controls, but even at the highest eoncentration Chlorella was still alive at the end of 23 days and had made appreciable growth. A better growth was obtained with sodium eitrate than without and this is probably related to a greater availability of iron as is indicated in the iron concentration of culture solutions not seeded with Chlorella.

\section{Experiment 10.}

This experiment was essentially the same as the one previously described, except that dextrose was supplied to each culture at a concentration of $1 \%$. The sugar was used merely to permit a more luxuriant growth and to know if under these conditions the toxicity of boron still prevails. At the conclusion of the experiment all of the cultures with sugar showed a distinctive chlorosis. The cultures instead of being deep green were of an orange color. This appeared first in the cultures containing boron but within a day or so the same condition was noted for the control. Dr. E. F. Hopkins of this laboratory suggested that the chlorosis observed was probably due to a lack of nitrogen. With the yield on a dry weight basis obtained and with the values reported by Muenseher (24) for the nitrogen requirement of Chlorella grown under similar conditions, it was possible to calculate the nitrogen content of Chlorella of my experiments. These data taken with the nitrogen content of the culture solutions sustained the conclusion that nitrogen was deficient. Nevertheless during the progress of the experiment no differences were noted between those cultures with boron and those without boron. Apparently sugar reduced markedly the toxicity of boron and a very considerable growth was obtained at a concentration of 140 p. p.m. This may be a matter of great significance.

\section{Experiment 11.}

In another experiment similar to the preceding one sucrose at a concentration of $1 \%$ was used. Here again no toxicity was obtained even with 80 p.p.m. In fact a greater growth was obtained with the higher concentration of boron. This was due probably to a greater inversion of sucrose at these higher concentrations. While no conclusions concerning the effect of the various concentrations of boron can be drawn from this experiment, the significant fact is presented that in the presence of sucrose boron had no toxic effect on chlorella. 
TABLE 11-EFFECT OF BORON ON THE GROWTH OF CHLORELLA SP. AND ON THE AVAILABILITY OF IRON.

\begin{tabular}{|c|c|c|c|c|}
\hline Treatment & $\begin{array}{l}\text { Boron } \\
\text { Concentra- } \\
\text { tion } \\
\text { p. p. m. }\end{array}$ & $\begin{array}{l}\text { Dry Weight } \\
\text { in Mgs. }\end{array}$ & $\begin{array}{l}\text { Iron } \\
\text { Concentra- } \\
\text { tion in } \\
\text { Mgs. }\end{array}$ & $\begin{array}{c}\text { Iron } \\
\text { Concentra- } \\
\text { tion in } \\
\text { Non-seeded } \\
\text { Cultures } \\
\text { Mgs. }\end{array}$ \\
\hline Full Nutrient........................... & ........ & 3.8 & 0.006 & 0.008 \\
\hline 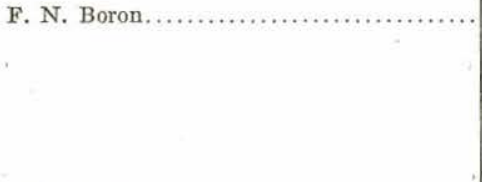 & $\begin{array}{r}10 \\
20 \\
40 \\
60 \\
80 \\
100 \\
120 \\
140\end{array}$ & $\begin{array}{l}2.2 \\
2.0 \\
1.9 \\
1.8 \\
2.1 \\
1.8 \\
1.2 \\
1.1\end{array}$ & $\begin{array}{l}0.006 \\
0.006 \\
0.009 \\
0.010 \\
0.007 \\
0.009 \\
0.008 \\
0.007\end{array}$ & $\begin{array}{l}0.008 \\
0.009 \\
0.010 \\
0.010 \\
0.009 \\
0.010 \\
0.010 \\
0.010\end{array}$ \\
\hline 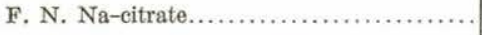 & n........... & 7.4 & 0.007 & 0.014 \\
\hline F. N. Boron and Na-Citrate............... & $\begin{array}{r}10 \\
20 \\
40 \\
60 \\
80 \\
100 \\
120 \\
140\end{array}$ & $\begin{array}{l}6.8 \\
5.2 \\
3.9 \\
3.2 \\
2.5 \\
1.8 \\
1.5 \\
1.5\end{array}$ & $\begin{array}{l}0.008 \\
0.010 \\
0.010 \\
0.010 \\
0.010 \\
0.008 \\
0.008 \\
0.010\end{array}$ & $\begin{array}{l}0.011 \\
0.018 \\
0.016 \\
0.020 \\
0.017 \\
0.020 \\
0.018 \\
0.017\end{array}$ \\
\hline
\end{tabular}

Duration of experiment-22 days.

Volume of solution-50 cc.

TABLE 12-EFFECT OF BORON ON THE GROWTH OF CHLORELLA SP. AND ON THE AVAILABILITY OF IRON IN THE PRESENCE OF SUGAR AND SODIUM CITRATE.

\begin{tabular}{|c|c|c|c|c|}
\hline Treatment & $\begin{array}{l}\text { Boron } \\
\text { Concentra- } \\
\text { tion } \\
\text { p. p. m. }\end{array}$ & $\begin{array}{l}\text { Dry Weight } \\
\text { in Mgs. }\end{array}$ & $\begin{array}{l}\text { Iron } \\
\text { Concentra- } \\
\text { tion in } \\
\text { Mgs. }\end{array}$ & $\begin{array}{c}\text { Iron } \\
\text { Concentra- } \\
\text { tion in } \\
\text { Non-seeded } \\
\text { Cultures } \\
\text { Mgs. }\end{array}$ \\
\hline 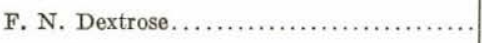 & $\ldots \ldots \ldots \ldots$ & 37.0 & 0.009 & 0.015 \\
\hline F. N. Boron and Dextrose.............. & $\begin{array}{r}10 \\
20 \\
40 \\
60 \\
80 \\
100 \\
120 \\
140\end{array}$ & $\begin{array}{l}34.5 \\
34.8 \\
34.2 \\
34.2 \\
34.5 \\
34.4 \\
31.4 \\
28.0\end{array}$ & $\begin{array}{l}0.008 \\
0.009 \\
0.008 \\
0.009 \\
0.009 \\
0.005 \\
0.006 \\
0.007\end{array}$ & $\begin{array}{l}0.020 \\
0.021 \\
0.022 \\
0.018 \\
0.017 \\
0.020 \\
0.018 \\
0.017\end{array}$ \\
\hline 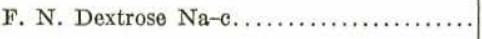 & $\ldots \ldots \ldots \ldots \ldots$ & 31.0 & 0.014 & 0.024 \\
\hline F. N. Boron Sodium Citrate and Dextrose. & $\begin{array}{r}10 \\
20 \\
40 \\
60 \\
80 \\
100 \\
120 \\
140\end{array}$ & $\begin{array}{l}36.2 \\
36.9 \\
39.4 \\
39.4 \\
39.0 \\
37.1 \\
35.4 \\
33.9\end{array}$ & $\begin{array}{l}0.013 \\
0.016 \\
0.010 \\
0.011 \\
0.014 \\
0.009 \\
0.010 \\
0.009\end{array}$ & $\begin{array}{l}0.020 \\
0.024 \\
0.023 \\
0.021 \\
0.024 \\
0.022 \\
0.022 \\
0.021\end{array}$ \\
\hline
\end{tabular}

Duration of experiment-22 days.

Volume of solution (50 cc.) 
TABLE 13-INFLUENCE OF BORON ON THE GROWTH OF CHLORELLA IN THE PRES ENCE OF SUCROSE.

\begin{tabular}{|c|c|c|c|}
\hline Boron Concentration & $\begin{array}{c}\text { Initial } \\
\mathrm{pH}\end{array}$ & $\begin{array}{c}\text { Final } \\
\mathrm{pH}\end{array}$ & $\begin{array}{l}\text { Dry Weight } \\
\text { Mgs. }\end{array}$ \\
\hline 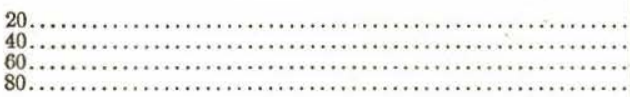 & $\begin{array}{l}4.3 \\
4.3 \\
4.3 \\
4.3\end{array}$ & $\begin{array}{l}5.58 \\
6.84 \\
6.53 \\
6.37\end{array}$ & $\begin{array}{l}27.6 \\
29.7 \\
38.9 \\
43.7\end{array}$ \\
\hline
\end{tabular}

Durztion of exprimsnt-30 days.

Volume of solution-50 cc.

\section{Discussion}

Several hypotheses have been offered by various investigators to explain the cause of chlorosis obtained when boron is present in the culture medium. Haas (8) in his studies on the toxic effect of boron on fruit trees reported an experiment in which lemon seedlings were grown in water cultures. Hoaglands solution plus 7.5 p.p.m. of boron and varying amounts of iron sulphate ranging from 5 to 105 p.p.m. was used. Photographic evidence of this experiment shows that increasing iron from 5 to 25 p. p. m. counteracted the apparent toxic symptoms of boron. Haas explains these results on the basis of a catalytic action of iron or a possible precipitation of boron as an insoluble ferric borate and thus a decrease in boron concentration. Sideris and Krauss (27) obtained chlorosis in the presence of boron only when the iron content was low. They suggested that the chlorosis was due to a lack of iron caused by the formation of an insoluble ferric borate. In explaining the stimulation obtained, when boron was present, they offer the possibility that iron may have been toxic. The formation of an insoluble ferric borate would decrease the iron concentration and therefore reduce the toxic effects. Furthermore, if boron were present in an amount sufficient to cause a toxic condition the addition of more iron would decrease the soluble boron content in the same manner. Skinner, Brown and Reid (28) in their studies on the effect of borax on plants under field conditions referred repeatedly to a "Bleaching" of the leaves, though reduced yield was noticed without chlorosis. They suggested "this prevention of chlorophyll formation may be due to interference with the assimilation of iron, similar to the action of calcium or as observed with an excess of manganese compounds." This implies an effect on the permeability of the cell by boron or accumulation.

In the work of Haas, Sideris and Krauss, and Skinner, Brown and Reid lemon seedlings, pineapple and corn plants were used respectively. In these plants the leaves are relatively far removed from the absorbing zone and it is possible that the chlorosis reported 
by these individuals may have been due to a relation between boron and iron. It is conceivable that boron might cause a precipitation of iron within the roots or stems and a shortage of iron would prevail in the leaves. Hence chlorosis would follow. A simple experiment of painting the leaves with a dilute iron salt possibly would have given evidence for the validity of this hypothesis.

In my own experiments a unicellular alga Chlorella was used in one series and the simple higher plant Spirodela polyrhyza in the other series. By using these plants the precipitation between the absorbing zone and the chlorophyllous region is minimized. This may account for the failure of marked chlorosis in my experiments. In the initial experiments with Spirodela slight chlorosis was observed in the presence of boron. This chlorosis disappeared with the addition of potassium tartrate. The controls lacking boron were also slightly chlorotic but less so than those with boron. The control plants also became greener with the addition of potassium tartrate. These data tend to confirm the viewpoint that there is a relation between boron toxicity and iron. Unfortunately the evidence in this case was not decisive.

In later experiments with Spirodelo under pure eultures no chlorosis was induced by boron. Similarly Chlorella failed to show chlorosis with high boron content. Chlorosis therefore is not necessarily a characteristic of boron injury. Reduced growth as noted by Skinner, Brown and Reid may result without chlorosis and my own results confirmed these conclusions. It is true that iron deficiency may result in decreased yield without chlorosis, ${ }^{*}$ so that these results are not entirely contradictory to the view exposed by Haas, Sideris and Krauss and others.

Analysis of iron showed no decrease of available iron in the culture solution used when boron is added. While a precipitate forms in the solution used and forms gradually, no boron was noted in the precipitate. The addition of potassium tartrate and of sodium citrate which increases the availability of iron while increasing growth did not reduce the toxicity of boron. The controls without boron were improved by the addition of tartrate or citrate, but comparing the boron cultures with these controls, they showed in general the usual increase or decrease of growth noted in those cultures without tartrate or citrate.

The results with sugar are suggestive. While further experiments of this character are necessary the results indicate that a plant with a high sugar content is more tolerant to boron than one with low

* Miller, E. D. Plant Physiology. p. 262. McGraw-Hill Book Co. (1931) 
sugar content. It is true that the nutrient medium containing sugar has a higher content of iron, but in view of the experiments with citrate and tartrate it seems more appropiate to assign the protective action to the sugar rather than to the iron.

\section{ACKNOWLEDGMents}

The writer wishes to express his gratitude to Dr. Lewis Knudson for his guidance, criticisms and helpful suggestions so freely given throughout the course of this work. Acknowledgment is also due to Dr. E. F. Hopkins for his suggestions and assistance.

\section{Summary}

1. Under the usual water-culture methods boron proved toxic to Spirodela polyrhyza at concentrations of above 1 p.p.m. Toxicity was evident in reduced growth, smaller plants, and loss of roots. In concentrations above 5 p. p. m. death soon occurred. Chlorosis was noted in all the cultures but those plants with boron were slightly more chlorotic than the controls. In both cases the addition of inorganic iron was without effect, but the addition of potassium tartrate at a concentration of 20 p. p. m. resulted in a marked chlorophyll development in all the cultures.

2. Under pure culture conditions boron seemed to increase growth at certain concentrations. At a concentration of 5 p. p. m. toxicity was apparent. No chlorosis was noted with boron.

3. With Chlorella under pure culture conditions marked stimulation was noted in experiments 6 and 7 with concentrations up to 10 p.p.m. and even with higher concentrations. In experiments 8,9 and 10 no stimulation was noted.

4. Chlorella proved extremely resistant to boron. A concentration of 30 p.p.m. was required to decrease growth on experiment 6 while in experiment 9 toxicity was noted at a concentration of 10 p.p.m. as evidenced by decreased growth, but survived at a concentration of 140 p. p. m. No chlorosis was noted in any case.

5. The addition of sodium eitrate or potassium tartrate, both of which tend to increase iron availability did not decrease the toxicity of boron when growth was taken as the eriterion.

6. The addition of dextrose to the culture medium increased growth as expected and made Chlorella much more resistant to boron. This was likewise true of sucrose.

7. Boron did not decrease the availability of iron.

8. Boron was not found present in the precipitation formed in the culture medium. The method of analysis used was not very sensitive. 


\section{BiBLIOGRAPHY}

1. Agulhon, Henri. Recherches sur la presence et la rôle du bore chez les vegetaux. These-Université de Paris Laval: L. Barneond et Cie. 1910.

2. Baumert, G. Zur Frage des norma len Workommens des Borsäure in Weine. Ber. Deut. Chem. Gesell. 21:3290-2. (1888)

3. Brenchley, W. . The action of certain compounds of zinc, arsenic and boron on the growth of plants. Ann. Bot. 28: 283-301. (1914).

4. - and Thornton. The relation between development, structure and function of the nodules of Vicia $f a b a$, as influenced by the presence or absence of boron in the nutrient medium. Proc. Roy. Soc. London B. 98: 373399. (1925).

5. —— and $\mathbf{K}$. Warrington. The role of boron in the growth of plants. Ann. Bot. 41:167-187. (1927).

6. Collins, $\boldsymbol{E}$. H. The influence of boron on the growth of the soybean plant. Soli Sci. 23: 83-105. (1927).

7. Emerson, $\mathbf{R}$. Relation between maximum rate of photosynthesis and chlorophyll concentration. Jour. Gen. Phys. 12:609623. (1929).

8. Haas, A. R. C. Toxic effect of boron on fruit trees. Bot. Gaz. 88: 113-131. (1929).

9. Boron as an essential element for healthy Growth of citrus. Bot. Gaz. 39:410. (1930).

10. Haas, A. R. C. and L. J. Klotz. Further evidence on the necessity of boron for health in citrus. Bot. Gaz. 32: 94. (1931).

11. Hopkins, F. F. and F. B. Wann. The effect of H-ion soncentration on the availability of iron for Chlorella sp. Jour. Gen. Phys. 9: 205-210. (1925).

12. - Iron requirement for Chlorella sp. Bot. Gaz. 84: 407-427. (1927).

13. - Iron-ion concentration in relation to growth and other biological processes. Bot. Gaz. 89: 209-239. (1930).

14. Hotter, E. Ueber das Workommen des Bors im Pflanzenreich un dessen pyhsiologische Bedeutung. Landw. Vers. Sta. 37: 437-58. (1890).

15. Jay, H. Sur la dispersion de l'acide borique dans la nature. Compt. rend. 121:896-9. (1895).

16. Johnston, E. S. and W. H. Dore. The relation of boron to the growth of the tomato plant. Science (U.S.) 67:324-325. (1928).

17. - The influence of boron on the chemical composition and growth of the tomato plant. Plant Physiology 4: 31-62. (1929).

18. Johnston, E. S. and P. L. Fisher. The essential nature of boron to the growth and fruiting of the tomato. Plant Physiology 5: 387-392. (1930). 
19. Kelley, W. P. and S. IM. Brown. Boron in the soil and irrigation waters of Southern California and its relation to citrus and walnut culture. Hilgarida 3:445-458. (1928).

20. Lippman, Æ. O. Ueber einige seltenere Bestandtheile der Rubnsache. Ber. Deut. Chem. Gesell. 21: 3492-3. (1888).

21. McHargue, J. S. and C. M. Shedd. The effect of manganese, copper, zine, boron and arsenic on the growth of oats. Jour. Amer. Soc. of Agron. 22: 739-746. (1930).

22. II cHargue, J. S. and R. IK. Calfee. Effect of boron on the growth of lettuce. Plant Phys. 7:161-164. (1932).

23. IMcIVIurtrey, J. I. The effect of boron on the growth of tobacco plants in aerated and unaerated solutions. Jour. Agri. Res. 38: 371-380. (1929).

24. IIuenscher, W. C. Protein synthesis in Chlorella. Bot. Gaz. 75: 249-267. (1923).

25. Nakamura, M. Can boric acid in high dilution exert a stimulant action on plants? Bull. Col. Agr. Tokyo Imp. Univ. 5: 509-12. (1903).

26. Scofield, C. and I. V. Wilcox. Boron in irrigation waters. U. S. D. A. Tech. Bull. 264. (1931).

27. Sideris, C. P. and B. H. Krauss. Carences minerales des plantes: Le rôle physiologique du fer, du titane, du manganese, du bore, et du fluor sur le development de l'Ananas Sativus et du Zea Mays. Tech. paper No. 29 Expt. Sta. of the Assoc. of "Hawaiian Pineapple Canners, Univ. of Hawaii.

28. Skinner, J. J., E. B. Brown and F. Reid. The effect of borax on the growth and yield of erops. U.S.D.A. Bull. 1126. (1923).

29. Sommer, A. I. The search for elements essential only in small amounts for plant growth. Science 66:482-484. (1927).

30. Sommer, A. I. and Lipman, C. B. Evidence of the indispensable nature of boron and zine for higher green plants. Plant Phys. 1: 231-249. (1926).

31. Sommer, A. I. and Sorokin Helen. Effects of the absence of boron and some other essential elements on the cell and tissue structure of the root tips of Pisum Sativum. Plant Phys. 3: 237-254. (1928).

32. Swanbach, T. R. The effect of boric acid on the growth of tobacco plants in nutrient solution. Jour. Plant Phys. 2: 475-485. (1927).

33. Warrington, $\mathbf{K}$. The effect of boric acid and borax on the broad bean and certain other plants. Ann. Bot. 37: 629-672. (1923).

34 The changes induced in the anatomical structure of Vicia faba by the absence of boron from the nutrient solution. Ann. Bot. 40:27-42. (1926).

35. Wittstein, D. and Apogier, F. Entdeckung der Borsäure im Pflanzenreiche, Ann. Chem. Pharm. 103: 362-364. (1857). 